\title{
Productivity, Storability and Economics of Microsprinkler Fertigation for Winter Onion (Allium cepa L.) in Semi-arid Conditions
}

\author{
D. D. Pawar, S. K. Dingre* and K. D. Kale \\ Mahatma Phule Krishi Vidyapeeth, Rahuri, Maharashtra, India \\ *Corresponding author
}

\section{Keyw ords \\ Microsprinkler, Foliar dose, Foliar fertilizer source, Storage losses, Water soluble fertilizers}

\section{Article Info}

\section{Accepted:}

18 May 2020

Available Online:

10 June 2020

\begin{abstract}
A B S T R A C T
Onion has very shallow root system that is frequently irrigated and fertilized with high fertilizer dose rates to maximize yield. Converting from furrow-fertigated to microsprinkler fertigated onion production may reduce fertilizer needs. The influence of fertigation sources and their levels, applied through microsprinkler irrigation on winter onion (Allium cepa L.) was evaluated for the years 2009-2011 under semi-arid region of India. The experiment was laid out in factorial randomized block design with nine treatments replicated thrice under microsprinkler system comprising three fertigation sources in main plots with three fertigation levels in sub plots. Fertigation by water soluble fertilizers sources improved plant height, neck thickness, polar and equatorial diameter, dry matter, bulb weight and green leaves weight. However, the differences in fertigation source urea+ urea phosphate + muriate of potash and urea+18:18:18 through microsprinkler was mostly non-significant. In fertigation levels, $100 \%$ and $80 \%$ recommended dose gave significantly higher values of growth and yield components than $60 \%$ level. The marketable bulb yield decreased with decrease in level of fertigation from 100 to $60 \%$ but not decreased significantly showed potential saving of $40 \%$ fertilizer cost by use of fertigation. The bulb storage losses in microsprinkler fertigation did not differed; but was higher under when conventional fertilizer source was used. The bulb storage losses were reduced with fertigation 60 to $100 \%$. Higher gross income, total net income, and the best benefit: cost ratio occurred with 60 and $100 \%$ microsprinkler fertigation. The treatment combination with application of $60 \%$ recommended dose of nutrients with urea+ urea phosphate + muriate of potash or urea+18:18:18 through microsprinkler in 10 weekly splits was optimum for growth, yield, storage and profit for winter onion cultivation.
\end{abstract}

\section{Introduction}

Onion (Allium cepa L.) is considered as one of the important commercial vegetable crops grown in India and the country ranks third among the onion producing countries in the world (Savitha et al., 2010). Land area dedicated for onion cultivation in India is 1.04 million ha, producing about 15.7 million tonnes of bulbs. At present per hectare 
productivity of onion in India is very low (15.1 t/ha) compared with the leading onion growing countries, like Korean republic, USA, Spain and Netherland, where productivity is ranged from 49 to $67 \mathrm{t} / \mathrm{ha}$ (Tripathi et al., 2010).

In onion water is a limiting factor for low productivity, and the common irrigation method is to flood the field which results in reduced water and fertilizer use efficiency due to different losses (Sankar et al., 2008). It could be possible to increase its production and productivity by using improved irrigation methods. Use of microsprinkler irrigation coupled with appropriate irrigation scheduling have been found suitable over traditional irrigation methods in terms of water saving, higher productivity and economics for onion. Microsprinklers with better water application efficiency provide the opportunity to create optimum soil moisture regime for shallow rooted crop like onion for better maturity and yield (Sarkara et al., 2008).

Onion bulb yield is affected by deficit supply of nutrients and therefore, irrigation and nutrients application should be delivered to provide the correct amount of nutrients and water required by onion (Rajput and Patel, 2006). In recent years greater importance has been focused to elevate productivity and efficiency of fertilizer through fertigation (Ajdary et al., 2007). Longer shelf-life of onion bulbs is another issue for obtaining better remunerative prices and for exporting. Water and nutrient management for onion influences storage behavior of bulbs (Sharma et al., 2010). Nitrogen adversely affects storability of onion bulb due to rotting and sprouting (Kumar et al., 2006). There has been always apprehension about suitability of micro sprinkler fertigation for crops. However, very few studies indicated its superiority over soil application of fertilizer (Prabhakar et al., 2011).
With microsprinkler, fertigation sources and fertigation levels are management variables which need to be investigated to enhance crop production. It is necessary to determine the economic viability of microsprinkler fertigation since water soluble fertilizers are more costly than conventional fertilizers. With this background, a study was under taken to characterize use of microsprinkler fertigation and contrast effects of different fertigation levels on growth, yield and economics of onion production.

\section{Materials and Methods}

\section{Experimental site}

The study was conducted at Mahatma Phule Krishi Vidyapeeth, Rahuri $\left(19^{0} 47^{\prime} \mathrm{N}\right.$ and $74^{0} 39^{\prime} \mathrm{E}$; altitude 500 meters above mean sea level) located in Maharashtra state of India during Winter seasons (November to April) of 2009-2011. The site lies in semiarid area with mean rainfall of $520 \mathrm{~mm}$ which is mostly concentrated during the monsoon months from June to September. The soil type was silty clay loam. The soil was $60 \mathrm{~cm}$ deep, slightly alkaline in nature with $\mathrm{pH}$ of 7.8 and electrical conductivity of $0.28 \mathrm{dSm}^{-1}$. Soil nutrient status indicated low N $(152.3 \mathrm{~kg}$ $\mathrm{ha}^{-1}$ ), and $\mathrm{P}\left(21.7 \mathrm{~kg} \mathrm{ha}^{-1}\right)$, but potassium was high $\left(360 \mathrm{~kg} \mathrm{ha}^{-1}\right)$. The soil had good drainage with infiltration rate of $3.24 \mathrm{~cm} \mathrm{hr}^{-1}$ and organic carbon content as $0.63 \%$. Moisture contents at field capacity $(32.2 \%)$ and permanent wilting point $(20.7 \%)$ indicated available water capacity of $11.5 \%$.

\section{Experimental design}

The experiment comprised of combinations of fertilizer sources: $\mathrm{S}_{1}$-Urea+ Urea phosphate $(17: 44: 0)+$ muriate of potash; $\mathrm{S}_{2}$-Urea + diammonium phosphate + muriate of potash, and $S_{3}$-urea+18:18:18. and the fertigation regimes of $60\left(D_{1}\right), 80\left(D_{2}\right)$ and $100 \%\left(D_{3}\right)$ 
recommended dose (RD) applied through microsprinkler.

The experiment was arranged in a split plot design. All treatments were replicated 3 times and repeated for 3 years. Urea (46:0:0), urea phosphate (17:44:0) and N18:P18: K18 are completely soluble in water (WSF); diammonium phosphate (DAP) is a cheap, conventional, fertilizer partially soluble in water. The soil was prepared by two harrowing and formed into on raised beds with $0.9 \mathrm{~m}$ top width and $1.20 \mathrm{~m}$ bottom width.

Onion seedlings (cv. N-2-4-1) were prepared in a nursery for transplanting in field. In nursery, the sowing of onion seeds was done on raised beds with $1.20 \mathrm{~m}$ top width and 1.50 bottom width. The nursery was irrigated by microsprinkler and after thirty days of raising nursery when seedlings attended the height of 25-30 cm, the onion seedlings were transplanted in field.

The nursery prepared seedlings was transplanted in 6 rows on each bed at spacing of $15 \mathrm{~cm}$ between rows and $7.5 \mathrm{~cm}$ between plants in rows. The experiment was arranged in a split plot design. All treatments were replicated 3 times and repeated for 3 years. The recommended fertilizer dose (100:50:50 $\mathrm{N}: \mathrm{P}_{2} \mathrm{O}_{5}: \mathrm{K}_{2} \mathrm{O} \mathrm{kg} \mathrm{ha}{ }^{-1}$ ) was applied in 10 weekly uniform splits through microsprinkler fertigation from transplanting and continued up to 70 days after transplanting.

\section{Microsprinkler system layout}

The microsprinkler system was constructed from PVC pipes of $90 \mathrm{~mm}$ and $63 \mathrm{~mm}$ dia used for main and submains, respectively. A screen filter was used to avoid clogging of nozzles due to physical impurities in irrigation water and precipitates in fertilizer solution. The duration of fertigation was controlled with a control valve positioned at the inlet of each manifold for each plot. The microsprinklers were placed on $16 \mathrm{~mm}$ diameter laterals and spacing between 2 laterals, and microsprinklers, on each lateral was $1.2 \times 1.2 \mathrm{~m}$. The rotating nozzles of 26 lph capacity at a height of $75 \mathrm{~cm}$ were installed with an application rate of $3.1 \mathrm{~mm}$ $\mathrm{h}^{-1}$. The system was operated at a constant pressure of $1.5 \mathrm{~kg} \mathrm{~cm}^{-2}$ maintained with a control valve. The average coefficient of uniformity for microsprinkler irrigation system was estimated as $82.5 \%$ in all the treatments. The microsprinkler irrigation was applied twice in a week on the basis of pan evaporation rate (Allen et al., 1998). The daily pan evaporation data was recorded from USWB class A Pan located at a site adjacent to the experimental area.

The recommended plant protection measures were performed as recommended by parent agricultural university. Irrigation was stopped 15 days before harvest. The bulbs were harvested after 16 weeks of planting at full maturity. After curing and neck cutting observations on yield contributing characters and bulb yield were recorded. A $10 \mathrm{~kg}$ sample of field cured onion bulbs were kept loose on a cement floor at $27^{\circ} \mathrm{C}$ to study the storage losses. Storage data were recorded at 30-day interval up to 180 days after harvest for rotting, physiological and total loss in weight.

The data were subjected to analysis of variance (ANOVA) using DRYSOFT statistical package. If an interaction was significant it was used to explain the results. Least significant difference (LSD) test was used to determine whether differences exist between certain comparisons. If interactions were not significant means were separated with least significant difference at $5 \%$ level of significance $(\mathrm{P}=0.05)$. The pooled analysis was done for all important characters of the study (Panse and Sukhatme, 1995). 


\section{Results and Discussion}

\section{Growth characters}

There was significant effect on growth characters of onion due to different fertigation sources and levels through microsprinklers. The $100 \%$ fertigation with source $S_{1}$ (urea + urea phosphate and MOP) resulted highest plant height at 60 days after transplanting $(34.63 \mathrm{~cm})$ however, it was at par with fertigation source $S_{3}$ (18: 18: 18). The plant height is an important yield attribute in onion and it has a direct relationship with bulb yield. The percentages of unmarketable bulbs like bolter and twins were at higher side $(0.58 \%$ and $2.30 \%$ ) in source $\mathrm{S}_{2}$ (Urea $+\mathrm{Di}$ ammonium phosphate + muriate of potash). The lesser bolter and twin bulbs in microsprinkler fertigated plots might be due to better availability of nutrients with reduction in leaching losses in water soluble fertilizer. The highest neck thickness was noticed in $S_{1}$ followed by $S_{3}$ however, the difference among fertigation sources was nonsignificant. Significant increase in bulb polar and equatorial diameter of bulbs were also obtained in $\mathrm{S}_{1}(6.32 \mathrm{~cm}$ and $5.47 \mathrm{~cm}$, respectively) and $S_{3}$ as compared to source $S_{2}$. This is in conformity with earlier findings of Kumar et al., (2006) that fertigation increases the growth parameters of onion crop.

All the growth characters were found improved with fertigation levels, but the difference was non-significant in most of the parameters. The interaction effect between fertigation sources and fertigation doses for all growth contributing character was found non-significant.

\section{Yield characters}

The dry matter, bulb weight, bulb yield, weight of leaves and bulb to leave ratio (Table 3 and 4) were significantly improved under microsprinkler fertigation. The higher dry matter (12.86 gm) and weight of onion bulb (86.72 gm) was obtained in $100 \%$ fertigation with $S_{1}$ source but was at par with $\mathrm{S}_{3}$. Comparison of fertigation levels showed a consistent increase in yield contributing parameters with increasing fertigation level from $60 \%$ to $100 \%$ but the difference was non-significant. More nutrient availability might have increased the translocation of photosynthates to storage organ of bulb resulting in increased weight of bulb. Prabhakar et al., (2011) also reported decrease in bulb weight with decreased nutrient concentration through fertigation. Almost similar trend was observed in other yield contributing characters. The source $S_{1}$ noticed highest weight of green leaves, followed by $S_{3}$. The fertigation of watersoluble fertilizers might have made nutrients available in adequate proportion, which resulted in triggering the weight of green leaves.

The interaction effect between fertigation sources and fertigation levels for all yield contributing characters were found nonsignificant.

\section{Marketable bulb yield}

The marketable bulb yield was observed higher in $S_{1}$ fertigated plots among all sources studied however, it was on par with source $S_{3}$. In fertigation levels bulb yield increased from 36.14 t.ha $^{-1}$ under $60 \%$ fertigation to a maximum of 38.97 t.ha $^{-1}$ under $100 \%$ fertigation but did not differed significantly. The increased bulb yield in fertigation was mostly due to favorable effects of nutrients throughout the crop period, its utilization and higher uptake (Sankar et al., 2008). However, fertigation sources and fertigation levels interaction effect on onion bulb yield was found non-significant. 
Table.1 Growth contributing characters of onion as influenced by different treatment

\begin{tabular}{|c|c|c|c|c|c|c|c|c|c|c|c|c|}
\hline \multirow[t]{2}{*}{ Sr. No } & \multicolumn{4}{|c|}{ Plant height at 60 days } & \multicolumn{4}{|c|}{ Bolting, \% } & \multicolumn{4}{|c|}{ Twin bulbs (\%) } \\
\hline & 2009 & 2010 & 2011 & Mean & 2009 & 2010 & 2011 & Mean & 2009 & 2010 & 2011 & Mean \\
\hline \multicolumn{13}{|c|}{ Fertigation source } \\
\hline $\mathbf{S}_{1}$ & 33.15 & 37.85 & 32.90 & 34.63 & 0.46 & 0.53 & 0.55 & 0.51 & 2.05 & 1.98 & 1.88 & 1.97 \\
\hline $\mathbf{S}_{2}$ & 31.63 & 36.40 & 31.45 & 33.16 & 0.56 & 0.61 & 0.58 & 0.58 & 2.37 & 2.31 & 2.23 & 2.30 \\
\hline $\mathbf{S}_{\mathbf{3}}$ & 32.50 & 37.04 & 32.40 & 33.98 & 0.52 & 0.56 & 0.55 & 0.54 & 2.12 & 2.08 & 2.00 & 2.06 \\
\hline C.D.at $5 \%$ & 0.75 & 1.01 & 0.6 & 1.41 & 0.03 & 0.02 & 0.01 & 0.02 & 0.3 & 0.2 & 0.25 & 0.2 \\
\hline \multicolumn{13}{|c|}{ Fertigation level } \\
\hline $\mathbf{D}_{1}$ & 31.56 & 36.78 & 30.85 & 33.06 & 0.52 & 0.59 & 0.56 & 0.56 & 2.03 & 1.96 & 1.91 & 1.97 \\
\hline $\mathbf{D}_{2}$ & 32.57 & 37.01 & 32.15 & 33.91 & 0.51 & 0.56 & 0.55 & 0.54 & 2.18 & 2.13 & 2.06 & 2.12 \\
\hline $\mathbf{D}_{3}$ & 33.15 & 37.49 & 33.75 & 34.80 & 0.51 & 0.56 & 0.56 & 0.54 & 2.33 & 2.26 & 2.14 & 2.24 \\
\hline C.D.at $5 \%$ & 1.29 & NS & NS & NS & NS & NS & NS & NS & 0.1 & 0.06 & 0.05 & 0.07 \\
\hline \multicolumn{13}{|l|}{ Interaction } \\
\hline C.D.at 5\% & NS & NS & NS & NS & NS & NS & NS & NS & NS & NS & NS & NS \\
\hline
\end{tabular}


Table.2 Neck thickness, polar and equatorial diameter of onion as influenced by different treatment

\begin{tabular}{|c|c|c|c|c|c|c|c|c|c|c|c|c|}
\hline \multirow[t]{2}{*}{ Sr. No } & \multicolumn{4}{|c|}{ Neck thickness (cm) } & \multicolumn{4}{|c|}{ Polar diameter (cm) } & \multicolumn{4}{|c|}{ Equatorial diameter $(\mathbf{c m})$} \\
\hline & 2009 & 2010 & 2011 & Mean & 2009 & 2010 & 2011 & Mean & 2009 & 2010 & 2011 & Mean \\
\hline \multicolumn{13}{|c|}{ Fertigation source } \\
\hline $\mathbf{S}_{1}$ & 1.37 & 1.46 & 1.45 & 1.42 & 5.78 & 6.62 & 6.56 & 6.32 & 5.44 & 5.60 & 5.36 & 5.47 \\
\hline $\mathbf{S}_{\mathbf{2}}$ & 1.25 & 1.37 & 1.50 & 1.37 & 5.45 & 6.72 & 6.41 & 6.19 & 5.12 & 5.35 & 5.26 & 5.24 \\
\hline $\mathbf{S}_{\mathbf{3}}$ & 1.31 & 1.37 & 1.47 & 1.38 & 5.63 & 6.45 & 6.61 & 6.23 & 5.54 & 5.20 & 5.31 & 5.35 \\
\hline C.D.at 5\% & NS & NS & NS & NS & 0.18 & 0.12 & 0.06 & 0.09 & 0.18 & 0.27 & NS & 0.22 \\
\hline \multicolumn{13}{|c|}{ Fertigation level } \\
\hline $\mathbf{D}_{1}$ & 1.24 & 1.37 & 1.41 & 1.34 & 5.54 & 6.64 & 6.44 & 6.21 & 5.28 & 5.40 & 5.18 & 5.29 \\
\hline $\mathbf{D}_{2}$ & 1.31 & 1.37 & 1.44 & 1.37 & 5.62 & 6.69 & 6.51 & 6.27 & 5.35 & 5.51 & 5.28 & 5.38 \\
\hline $\mathbf{D}_{\mathbf{3}}$ & 1.37 & 1.47 & 1.57 & 1.47 & 5.70 & 6.45 & 6.64 & 6.26 & 5.47 & 5.23 & 5.48 & 5.39 \\
\hline C.D.at 5\% & NS & NS & NS & NS & NS & NS & NS & NS & NS & NS & NS & NS \\
\hline \multicolumn{13}{|l|}{ Interaction } \\
\hline C.D.at 5\% & NS & NS & NS & NS & NS & NS & NS & NS & NS & NS & NS & NS \\
\hline
\end{tabular}


Table.3 Effect of micro sprinkler fertigation on TSS, dry matter and average bulb weight of onion

\begin{tabular}{|c|c|c|c|c|c|c|c|c|c|c|c|c|}
\hline \multirow[t]{2}{*}{ Sr. No } & \multicolumn{4}{|c|}{ TSS (\%) } & \multicolumn{4}{|c|}{ Dry matter (gm) } & \multicolumn{4}{|c|}{ Average bulb weight (gm) } \\
\hline & 2009 & 2010 & 2011 & Mean & 2009 & 2010 & 2011 & Mean & 2009 & 2010 & 2011 & Mean \\
\hline \multicolumn{13}{|c|}{ Fertigation source } \\
\hline $\mathbf{S}_{1}$ & 11.28 & 11.30 & 11.40 & 11.32 & 13.63 & 13.39 & 11.57 & 12.86 & 90.30 & 70.70 & 99.17 & 86.72 \\
\hline $\mathbf{S}_{\mathbf{2}}$ & 10.98 & 11.00 & 10.95 & 10.98 & 13.00 & 13.00 & 11.07 & 12.35 & 77.19 & 64.96 & 91.97 & 78.04 \\
\hline $\mathbf{S}_{\mathbf{3}}$ & 11.14 & 11.19 & 11.18 & 11.17 & 13.17 & 13.22 & 11.32 & 12.57 & 83.60 & 67.99 & 97.82 & 83.14 \\
\hline C.D.at 5\% & 0.10 & NS & 0.09 & 0.09 & 0.56 & NS & 0.34 & 0.49 & 6.1 & 5.7 & 6.9 & 7.9 \\
\hline \multicolumn{13}{|c|}{ Fertigation level } \\
\hline $\mathbf{D}_{1}$ & 11.07 & 11.13 & 11.23 & 11.14 & 13.08 & 13.02 & 11.10 & 12.40 & 81.66 & 65.74 & 92.72 & 80.04 \\
\hline $\mathbf{D}_{2}$ & 11.17 & 11.18 & 11.18 & 11.17 & 13.19 & 13.21 & 11.30 & 12.57 & 83.21 & 67.51 & 97.79 & 82.84 \\
\hline $\mathbf{D}_{3}$ & 11.16 & 11.19 & 11.13 & 11.16 & 13.54 & 13.36 & 11.55 & 12.82 & 86.21 & 70.41 & 98.45 & 85.02 \\
\hline C.D.at 5\% & NS & NS & NS & NS & NS & NS & NS & NS & NS & NS & NS & NS \\
\hline \multicolumn{13}{|l|}{ Interaction } \\
\hline C.D.at 5\% & NS & NS & NS & NS & NS & NS & NS & NS & NS & NS & NS & NS \\
\hline
\end{tabular}


Table.4 Yield and yield contributing parameters of onion under different fertigation sources and their levels

\begin{tabular}{|c|c|c|c|c|c|c|c|c|c|c|c|c|}
\hline \multirow[t]{2}{*}{ Sr. No } & \multicolumn{4}{|c|}{ Bulb yield (t ha $\left.{ }^{-1}\right)$} & \multicolumn{4}{|c|}{ Wt. of green leaves $\left(\mathrm{tha}^{-1}\right)$} & \multicolumn{4}{|c|}{ Bulb to leaves ratio } \\
\hline & 2009 & 2010 & 2011 & Mean & 2009 & 2010 & 2011 & Mean & 2009 & 2010 & 2011 & Mean \\
\hline \multicolumn{13}{|c|}{ Fertigation source } \\
\hline $\mathbf{S}_{1}$ & 47.34 & 31.45 & 39.23 & 39.07 & 6.80 & 4.25 & 5.23 & 5.43 & 6.76 & 7.42 & 7.43 & 7.20 \\
\hline $\mathbf{S}_{2}$ & 42.56 & 27.93 & 37.07 & 35.86 & 6.57 & 3.60 & 4.85 & 5.01 & 6.61 & 7.56 & 7.56 & 7.24 \\
\hline $\mathbf{S}_{\mathbf{3}}$ & 44.62 & 29.21 & 38.41 & 37.69 & 6.74 & 3.84 & 5.08 & 5.22 & 6.63 & 7.60 & 7.70 & 7.31 \\
\hline C.D.at 5\% & 2.90 & 2.44 & 1.82 & 2.89 & 0.12 & 0.42 & 0.20 & 0.25 & NS & NS & NS & NS \\
\hline \multicolumn{13}{|c|}{ Fertigation level } \\
\hline $\mathbf{D}_{1}$ & 42.93 & 28.24 & 37.24 & 36.14 & 6.67 & 3.70 & 4.78 & 5.05 & 6.56 & 7.60 & 7.86 & 7.34 \\
\hline $\mathbf{D}_{2}$ & 44.62 & 29.75 & 38.13 & 37.50 & 6.70 & 3.95 & 5.08 & 5.24 & 6.64 & 7.49 & 7.51 & 7.21 \\
\hline $\mathbf{D}_{\mathbf{3}}$ & 46.97 & 30.61 & 39.34 & 38.97 & 6.74 & 4.05 & 5.30 & 5.36 & 6.80 & 7.50 & 7.31 & 7.20 \\
\hline C.D.at 5\% & NS & NS & NS & NS & NS & NS & NS & NS & NS & NS & NS & NS \\
\hline \multicolumn{13}{|l|}{ Interaction } \\
\hline C.D.at 5\% & NS & NS & NS & NS & NS & NS & NS & NS & NS & NS & NS & NS \\
\hline
\end{tabular}


Int.J.Curr.Microbiol.App.Sci (2020) 9(6): 1096-1109

Table.5 Water use by onion as influenced by different treatments

\begin{tabular}{|c|c|c|c|c|c|c|c|c|}
\hline \multirow[t]{2}{*}{ Sr. No } & \multicolumn{4}{|c|}{ Water depth (mm) } & \multicolumn{4}{|c|}{ FWUE (kg ha $\left.{ }^{-1} \mathrm{~mm}\right)$} \\
\hline & 2009 & 2010 & 2011 & Mean & 2009 & 2010 & 2011 & Mean \\
\hline \multicolumn{9}{|c|}{ Fertigation source } \\
\hline $\mathbf{S}_{1}$ & \multirow[t]{3}{*}{375.0} & \multirow[t]{3}{*}{428.0} & \multirow[t]{3}{*}{404.3} & \multirow[t]{3}{*}{402.4} & 126.2 & 73.5 & 95.0 & 98.2 \\
\hline $\mathbf{S}_{2}$ & & & & & 113.5 & 65.3 & 91.7 & 90.2 \\
\hline $\mathbf{S}_{3}$ & & & & & 119.0 & 68.2 & 97.0 & 94.8 \\
\hline \multicolumn{9}{|c|}{ Fertigation level } \\
\hline $\mathbf{D}_{1}$ & \multirow[t]{3}{*}{375.0} & \multirow[t]{3}{*}{428.0} & \multirow[t]{3}{*}{404.3} & \multirow[t]{3}{*}{402.4} & 114.5 & 66.0 & 92.1 & 90.9 \\
\hline $\mathbf{D}_{2}$ & & & & & 119.0 & 69.5 & 94.3 & 94.3 \\
\hline $\mathbf{D}_{3}$ & & & & & 125.3 & 71.5 & 97.3 & 98.0 \\
\hline
\end{tabular}


Table.6 Storage loses in onion as influenced by different treatments (Average of 3 years)

\begin{tabular}{|c|c|c|c|c|c|c|c|c|c|c|c|c|c|}
\hline \multirow{2}{*}{\multicolumn{2}{|c|}{\begin{tabular}{l|l|}
$\begin{array}{l}\text { Sr. } \\
\text { No. }\end{array}$ & Treatments \\
\multicolumn{2}{|l}{ Days after harvesting } \\
\end{tabular}}} & \multicolumn{4}{|c|}{ Rooting losses (\%) } & \multirow{2}{*}{$\begin{array}{l}\text { Total } \\
\text { loss } \\
(\%)\end{array}$} & \multicolumn{6}{|c|}{ Physiological weight loss (\%) } & \multirow{2}{*}{$\begin{array}{l}\text { Total } \\
\text { loss }(\%)\end{array}$} \\
\hline & & 90 & 120 & 150 & 180 & & 30 & 60 & 90 & 120 & 150 & 180 & \\
\hline \multicolumn{14}{|c|}{ Fertilizer source } \\
\hline $\mathbf{S}_{1}$ & $\begin{array}{l}\text { Urea phosphate + } \\
\text { Urea + MOP }\end{array}$ & 2.29 & 2.51 & 2.98 & 4.04 & 11.82 & 2.0 & 3.17 & 4.13 & 6.25 & 8.08 & 11.42 & 35.05 \\
\hline $\mathbf{S}_{\mathbf{2}}$ & $\mathrm{DAP}+\mathrm{Urea}+\mathrm{MOP}$ & 2.41 & 2.84 & 3.36 & 4.56 & 13.17 & 2.82 & 3.71 & 4.58 & 6.85 & 8.96 & 12.47 & 39.39 \\
\hline \multirow[t]{2}{*}{$\mathbf{S}_{\mathbf{3}}$} & 18:18:18 + Urea & 2.36 & 2.66 & 3.17 & 4.27 & 12.46 & 2.15 & 3.36 & 4.37 & 6.55 & 8.80 & 12.22 & 37.45 \\
\hline & LSD@5\% & 0.07 & 0.13 & 0.17 & 0.09 & -- & 0.13 & 0.17 & 0.17 & 0.26 & 0.07 & 0.14 & -- \\
\hline \multicolumn{14}{|c|}{ Fertigation levels } \\
\hline $\mathbf{D}_{1}$ & $60 \%$ Fertigation & 2.33 & 2.65 & 3.38 & 4.11 & 12.47 & 2.21 & 3.01 & 4.24 & 6.27 & 7.93 & 11.15 & 34.81 \\
\hline $\mathbf{D}_{2}$ & $80 \%$ Fertigation & 2.36 & 2.67 & 3.67 & 4.82 & 13.52 & 2.35 & 3.40 & 4.62 & 6.54 & 8.29 & 12.36 & 37.56 \\
\hline \multirow[t]{4}{*}{$\mathbf{D}_{3}$} & $100 \%$ Fertigation & 2.37 & 2.69 & 3.95 & 4.94 & 13.95 & 2.53 & 3.69 & 4.84 & 6.88 & 8.62 & 12.51 & 39.07 \\
\hline & LSD@ $9 \%$ & 0.07 & 0.13 & 0.17 & 0.09 & -- & 0.13 & 0.17 & 0.17 & 0.26 & 0.07 & 0.14 & -- \\
\hline & \multicolumn{13}{|l|}{ Interaction } \\
\hline & LSD@ 5\% & N.S. & N.S. & N.S. & N.S. & -- & N.S. & N.S. & N.S. & N.S. & N.S. & N.S. & -- \\
\hline
\end{tabular}


Table.7 Cost economics as influenced by different treatments

\begin{tabular}{|c|c|c|c|c|c|c|c|c|c|c|c|c|}
\hline \multirow[t]{2}{*}{ Sr. No } & \multicolumn{4}{|c|}{ Total seasonal cost Rs. ha $^{-1}$} & \multicolumn{4}{|c|}{ Net seasonal income, Rs. ha ${ }^{-1}$} & \multicolumn{4}{|c|}{ Benefit cost ratio ha ${ }^{-1}$} \\
\hline & 2009 & 2010 & 2011 & Mean & 2009 & 2010 & 2011 & Mean & 2009 & 2010 & 2011 & Mean \\
\hline \multicolumn{13}{|c|}{ Fertigation source } \\
\hline $\mathbf{S}_{1}$ & 52385 & 61414 & 61414 & 58404 & 184298 & 190186 & 130653 & 168379 & 3.52 & 3.10 & 2.13 & 2.91 \\
\hline $\mathbf{S}_{\mathbf{2}}$ & 47677 & 57374 & 57374 & 54142 & 165123 & 166092 & 127992 & 153069 & 3.46 & 2.90 & 2.23 & 2.86 \\
\hline $\mathbf{S}_{\mathbf{3}}$ & 57187 & 70342 & 70342 & 65957 & 165913 & 163365 & 125791 & 151690 & 2.90 & 2.33 & 1.79 & 2.34 \\
\hline \multicolumn{13}{|c|}{ Fertigation level } \\
\hline $\mathbf{D}_{1}$ & 50875 & 60593 & 60593 & 57354 & 163758 & 165301 & 125624 & 151561 & 3.23 & 2.74 & 2.08 & 2.68 \\
\hline $\mathbf{D}_{2}$ & 52300 & 63081 & 63081 & 59487 & 170800 & 174919 & 127586 & 157768 & 3.28 & 2.80 & 2.04 & 2.71 \\
\hline $\mathbf{D}_{3}$ & 54074 & 65456 & 65456 & 61662 & 180776 & 179424 & 131227 & 163809 & 3.37 & 2.78 & 2.03 & 2.73 \\
\hline
\end{tabular}




\section{Field water use efficiency}

The total water applied to onion crop through microsprinkler was $402 \mathrm{~mm}$ which is almost half to water applied through reported conventional irrigation $(800 \mathrm{~mm})$ The maximum field water use efficiency (FWUE) of $98.2 \mathrm{~kg} \mathrm{ha}^{-1} \mathrm{~mm}^{-1}$ was observed under $\mathrm{S}_{1}$ source whereas minimum water use efficiency observed with application of conventional fertilizers $\left(90.2 \mathrm{~kg} \mathrm{ha}^{-1} \mathrm{~mm}^{-1}\right)$. In fertigation levels, the FWUE was highest in $100 \%$ dose $\left(98 \mathrm{~kg} \mathrm{ha}^{-1} \mathrm{~mm}^{-1}\right)$. Lowest FWUE of $90.9 \mathrm{~kg}$ $\mathrm{ha}^{-1} \mathrm{~mm}^{-1}$ was recorded in microsprinkler $60 \%$ fertigation (Table 5). This is in confirmation with the findings of Sarkara et al., (2008) that microsprinkler can increase the water use efficiency by increasing crop yield.

\section{Storage losses}

\section{Rotting percentage}

Rotting losses decreased under fertigation with water soluble fertilizers as compared to control. The rooting losses were found in increasing trend with the increase in storage period (Table 6). It was significantly higher in source $\mathrm{S}_{2}(13.17 \%)$ whereas least losses were observed in fertigation source $\mathrm{S}_{1}(11.82 \%)$ and it did not differ significantly with source $\mathrm{S}_{3}(12.46 \%)$. Similar trend of loss in weight was observed in three years.

The increasing trend for rotting loss was observed with increase in fertigation from 60 to $100 \%$ for microsprinkler fertigated onion. Maximum losses were recorded in $100 \%$ fertigation $(13.95 \%)$ followed by $80 \%$ $(13.52 \%)$ and $60 \%$ fertigation (12.47\%). The higher weight loss during storage with $100 \%$ fertigation may be attributed to higher nutrient application. Higher nutrient dose may ensure greater uptake of nitrogen by the crop which caused spoilage of bulb due to rotting. Kumar et al., (2006) reported that high doses of nitrogen fertigation had adverse effect on storability of onion bulb due to rotting. However, interaction between fertigation sources and levels was found non-significant.

\section{Physiological loss in weight}

Physiological loss increased with conventional fertilizer application (Table 6). The least physiological loss in weight was observed in fertigation source $\mathrm{S}_{1}(35.05 \%)$ and it did not differ significantly with source $\mathrm{S}_{3}(37.45 \%)$, while source $\mathrm{S}_{2}$ resulted in significantly higher losses $(39.39 \%)$.

Physiological loss in bulb storage was found very responsive to nutrient applied. The highest dose of fertigation i.e. $100 \%$ recorded maximum physiological loss (39.07\%) followed by $80 \%(37.56 \%)$ and $60 \%$ fertigation $(34.81 \%)$. Higher loss with higher fertility level might be due to the fact that higher nitrogen availability to crop during production phase might be accelerated the losses during storage. Woldetsadik et al., (2003) also observed that high level of nitrogen fertilization promotes losses in onion. However, interaction between fertigation sources and levels was found nonsignificant.

\section{Cost economics}

In terms of three years pooled economics, the total seasonal cost computed by adding the seasonal cost of microsprinkler system and onion cultivation cost considering 4 months crop period (Table 7). The seasonal cost of microsprinkler system for onion was estimated as Rs. 7192/ considering depreciation cost, interest on capital investment and cost towards repairs and maintenance. The higher cost of cultivation in fertigation could be attributed to high market cost of water-soluble fertilizers. 
The beneficial effect of higher yield through microsprinkler fertigation is attributed to the higher seasonal income. Among different sources and fertigation levels, source $\mathrm{S}_{1}$ (Rs. $168379 \mathrm{ha}^{-1}$ ) and $100 \%$ fertigation (Rs. $163809 \mathrm{ha}^{-1}$ ) recorded higher seasonal income. Higher productivity resulted into B:C ratio of 2.91 in $S_{1}$ however, it was almost equal with $\mathrm{S}_{2}$ due to lower prices of conventional fertilizers.

In conclusion, foliar application of fertilizers through microsprinkler significantly improved the growth, yield and economic benefits of closely spaced onion. Among the various sources tested over 3 years, foliar application of fertilizers with source $\mathrm{S}_{1}$ (urea + urea phosphate + MOP) and $S_{3}$ (Urea $\left.+18: 18: 18\right)$ were found suitable in improving the productivity and economics returns from onion cultivation. Among different fertigation levels tested, no significant difference in growth, yield and economical parameters was noticed and $60 \%$ fertigation through microsprinkler was observed as optimum option. The storage losses were significantly lower in foliar application of fertilizers however, $100 \%$ fertigation level recorded higher storage losses. There is a marked increase in economic parameters under microsprinkler fertigation. The overall results of study revealed that $60 \%$ foliar application of water-soluble fertilizers through microsprinkler is advisable to farmers for improved growth, yield, economics and storage behavior of onion in semi-arid regions of India.

\section{References}

Ajdary, K., D.K. Singh, A.K. Singh, and M. Khanna. 2007. Modeling of nitrogen leaching from experimental onion field under microsprinkler fertigation. Agricultural Water Management 89(12): $15-28$.
Allen, R.G., L.S. Pareira, D. Raes, and M. Smith. 1998. Crop-evapotranspiration. Guidelines for computing crop water requirements. Irrigation and drainage paper 56, Food and Agriculture Organization of the United Nations, Rome, Italy.

Kumar S., A. Kumar, and G. Mandal. 2006. Effect of irrigation scheduling and fertigation on storability of onion (Allium Cера) under microsprinkler irrigation regime. Indian Journal of Agricultural Sciences 76(7): 401-404.

Panse V. G. and Sukhatme P. V. (1995). Statistical methods for agricultural workers, ICAR, New Delhi.

Prabhakar, M., S.S. Hebbar, and A.K. Nair. 2011. Effect of microsprinkler fertigation on growth and yield of rabi onion. Journal of Horticultural Sciences 6(1): 66-68.

Rajput, T.B.S., and N Patel. 2006. Water and nitrate movement in drip irrigated onion under fertigation and irrigation treatments. Agricultural Water Management 79: 293-311.

Sankar, V., K.E. Lawande, and P.C. Tripathi. 2008. Effect of micro-irrigation on growth, yield and water use efficiency of onion (Allium cepa) under western Maharashtra conditions. Indian Journal of Agricultural Sciences 78(7):584-588.

Sarkara, S., S.B. Goswamib, S. Mallickc, and M.K. Nandaa. 2008. Different indices to characterize water use pattern of microsprinkler irrigated onion (Allium cepa L.). Agricultural Water Management 95(5):625-632.

Savitha, B.K., P. Paramaguru, and L. Pugalendhi. 2010. Effect of drip fertigation on growth and yield of onion. Indian Journal of Horticulture 67(special issue): 334-336.

Sharma, A.K., R.S. Bhatia, and R. Raina. 2010. Effect of nitrogen and phosphorus on growth and bulb yield of kharif 
onion (Allium cepa L.) crop raised through sets in the lower hills of Himachal Pradesh. Progressive Horticulture 42: 84-87.

Tripathi, P.C., V. Sankar, and K.E. Lawande. 2010. Influence of micro-irrigation methods on growth, yield and storage of rabi onion. Indian Journal of
Horticulture 67(1): 61-65.

Woldetsadik, K., U. Gertsson, and J. Ascard. 2003. Shallot yield quality and storability as affected by irrigation and nitrogen. Journal of Horticultural Science and Biotechnology 78(4): 549553.

\section{How to cite this article:}

Pawar, D. D., S. K. Dingre and Kale, K. D. 2020. Productivity, Storability and Economics of Microsprinkler Fertigation for Winter Onion (Allium cepa L.) in Semi-arid Conditions. Int.J.Curr.Microbiol.App.Sci. 9(06): 1096-1109. doi: https://doi.org/10.20546/ijcmas.2020.906.136 